\title{
The Impact of Principal's Leadership in Guidance and Counseling Services on Self-Development of Senior High School Students
}

\author{
Salman Tumanggor \\ Universitas Islam Negeri Syarif Hidayatullah Jakarta, Indonesia \\ هalmantumanggor2019@gmail.com
}

\begin{abstract}
Guidance and counseling services in school should be created as a realistic program to gain student's interests. The effort to improve student's selfdevelopment in senior high school can be done through the principal leadership approach. The purpose of studies to determine the role of principal leadership in guidance and counseling services with student's selfdevelopment. The participants were selected using purposive sampling from several seniors high school at Banten province, Indonesia. The author uses a descriptive analysis method of correlation with the quantitative approach. 40 items of principal leadership scale $(\alpha=0.930)$ and 120 items of student's self-development $(\alpha=0.978$ ) were used to collect the data. The results show there are significant relationships $(r 2=0.495, p<0.05)$ and impact $(\beta=0.736, p<0.05)$ between principal leadership with student's self-development. The student's self-development is determined by principal leadership in guidance and counseling services.
\end{abstract}

Revised November 16, 2019

Accepted January 4, 2020

Keywords: guidance and counseling; school principals; self-development; students

\section{INTRODUCTION}

In educational context, everyone must be responsible for achieving the specified goals. The school is a unique organization, because it consists of various individuals with diverse ages, social, economic, cultural, and purpose. Therefore, the school has additional tasks and functions such as helping solve various problems. According to Komariah \& Triatna (2010) schools are complex systems because being composed of input-process-output they also have accountability for the context and outcomes of education.

One of the school programs that students can use is guidance and counseling services. Guidance and counseling services are basically a form of operationalization of the concept of guidance and counseling that is intended to meet various principles, functions and objectives set. Barida (2016) said there are four areas of guidance in guidance and counseling namely career, learning, personal, and social. These four fields are professional spaces for counselors in conducting guidance and counseling activities.

To develop the potential of students in schools, guidance and counseling services are not being the first choice. Kurnianto (2018) said that the implementation of guidance and counseling services in schools did not go well, because the burden of counselors had taken up his time as a classroom as a teacher so that guidance and counseling programs were often ignored. Indeed guidance and counseling can be one of the programs for student selfdevelopment.

Self-development program is an effort to help students develop under each potential, providing opportunities for students to develop and express themselves according to their

How to cite:

E-ISSN:

Published by:
Tumanggor, S. (2020). The Impact of Principal Leadership in Guidance and Counseling Services on SelfDevelopment of Senior High School Students. Islamic Guidance and Counseling Journal, 3(2). https://doi.org/10.25217/igcj.v3i2.550

2614-1566

Institut Agama Islam Ma'arif NU (IAIMNU) Metro Lampung 
needs, interests, conditions, and development. Counselors help students recognize their potential talents and interests. Furthermore, students are assisted in analyzing their strengths and weaknesses, so that they can understand themselves, accept themselves, direct and can make the right decisions in planning related to education, career, and other life planning (Gysbers, 2001, 2004; Gysbers \& Henderson, 2014).

Self-development is an assistance service for students both individuals and groups to develop optimally in personal, social, learning, and career through a process of habituation, self-understanding and the environment as well as its benefits to achieving optimum selfdevelopment (Coogan \& Chen, 2007; Pieterse et al., 2013). This service aims to make students independent by developing their potential, talents, and uniqueness for their happiness in life. Self-development also means developing students' personalities. Therefore, selfdevelopment also means developing aspects of personality (Balin \& Hirschi, 2010; Pellitteri, 2010). These aspects of personality include self-confidence, independence, emotional skills, social maturity, cooperative ability, achievement motivation, tenacity, talent or interest, creativity, and insight and career planning (Heilat \& Seifert, 2019; Hughes et al., 2017; Hussin et al., 2020; Rupani et al., 2014).

To support student self-development, schools should prepare all targeted activities so guidance and counseling services will run well. One important factor influencing student's self-development program is the principals leadership. Positive principal's leadership can encourage all the resources at the school. Counselors performance who specifically provide services to students and technical facilities can be met with managerial support from the school. The principal has a major role in ensuring the effectiveness of guidance and counseling services. If the principal does not provide adequate support, then counseling does not go well. In other words, the principal's support has an effect on the effectiveness of guidance and counseling services (Armstrong et al., 2010; Bardhoshi \& Duncan, 2009; Leuwerke et al., 2009; Lieberman, 2004; Ponec \& Brock, 2000; Shoffner \& Williamson, 2000).

Some researchers have pointed out how important the principal's role is in supporting guidance and counseling programs (Ponec \& Brock, 2000; Shoffner \& Williamson, 2000). Even school principals can provide discussion space for school personnel in explaining the role of guidance and counseling (Lieberman, 2004). However, not a few principals have a wrong understanding of guidance and counseling and have a negative impact on service delivery (Bardhoshi \& Duncan, 2009; Leuwerke et al., 2009). Armstrong et al. (2010) also shows that counselor readiness influences the support of school principals.

Some of the researchers focused on the counselor's relationship with the school principals and the readiness of the guidance and counseling service program. In this paper the author focuses on how the principal's leadership role is in guidance and counseling services. The purpose of this paper is to determine the role of the principal in the guidance and counseling service on student self-development.

\section{METHODS}

The author uses the correlational method with a quantitative approach. 254 students participated from five public high schools in Tangerang City, Indonesia. The author asks participants to fill in the scale after obtaining approval from the school. There is no follow-up to obtain further data. So, it can be said that this study is cross-sectional in nature.

There are two scales used to measure the research construct, namely the scale of student self-development and the principal's leadership scale. The student self-development scale consists of 120 items $(\alpha=0.930)$ and the principal's leadership scale consists of 40 items $(\alpha=$ 0.978). The higher the scores obtained by the participants the better the personal development of the students and leadership undertaken by the principal. 


\begin{tabular}{ccccc}
\hline \multirow{2}{*}{ Category } & $\begin{array}{c}\text { Students self-development } \\
(\mathrm{N}=254)\end{array}$ & $\begin{array}{c}\text { Principal's leadership } \\
(\mathrm{N}=254)\end{array}$ \\
\cline { 2 - 5 } & $\mathrm{F}$ & $\%$ & $\mathrm{~F}$ & $\%$ \\
\hline Bad & 7 & $2.75 \%$ & 5 & $1.97 \%$ \\
Good & 21 & $8.27 \%$ & 29 & $11.42 \%$ \\
Excellent & 226 & $88.98 \%$ & 220 & $86.61 \%$ \\
\hline
\end{tabular}

Table 1. Self-development and leadership of the school principals

The author analyzes the data collected using correlational analysis. Before carrying out a correlational analysis the authors conducted several prerequisite tests such as the normality test, the data confirmed normal $(\mathrm{p}>0.05)$ and homogeneity test, the data confirmed homogeneous $(\mathrm{p}>0.05)$.

\section{RESULTS AND DISCUSSION}

The recapitulation results by category of students' level of self-development and the leadership of the school principal in the guidance and counseling services at school are shown in Table 1. It is known that out of 254 students there are 7 students who have selfdevelopment in the bad category $(2.75 \%), 21$ students have self-development in the good category $(8.27 \%)$ and 226 students who have self-development in the Excellent category $(88.75 \%)$. This shows that in general the students' self-development in the excellent category means that students have received guidance and counseling services at the school by involving all responsible parties. It is known that out of 254 students there were 5 students who thought that the leadership of the school principals was in the bad category $(1.97 \%), 29$ students thought the leadership of the school principal was in the good category $11.42 \%$ ) and 220 students who thought the leadership of the school principals was in the excellent category (86.61\%). This shows that in general the leadership of principals in the excellent category means that principals have performed their duties in the guidance and counseling services following their duties and responsibilities as school principals.

The regression analysis shows that every improvement in principal's leadership will leads to an increase in students' self-improvement $(\beta=0.736, p<0.05)$. The strength of the relationship between the principal's leadership and student self-development is shown by the very significant correlation coefficient $\left(\mathrm{r}^{2}=0.495<0.05\right)$. Thus there is a positive relationship between the principal's leadership and student self-development or in other words the higher the principal's leadership, the higher the student's self-development.

An important finding in this study is that there is a positive relationship between the principal's leadership and student self-development. The results of this study indicate that guidance and counseling services in schools require direction from the principal's which aims to make all components in the school work to achieve the goals planned. The ability to manage programs owned by the principals will bring an educational atmosphere and sufficient for teachers and students in the school environment (Keetanjaly et al., 2019). In addition to make school programs implemented properly, managerial leadership can also have a positive impact on teachers in schools. Kulsum (2013) states that the strategic role of the principal must have a vision of guidance and counseling which is one way to achieve educational goals. Principal's leadership was declared very good, so that the implementation of guidance and counseling services would be good, this finding is also in line with the opinion of Prayitno \& Amti (2004) saying that the education process will run well if it integrates three main components namely, the administrating, teaching, and counseling.

The role of the principal as a leader in the school becomes important to support the performance of the counselor because the principal becomes the school manager who manages the school's human resources to conduct a quality educational process. Throughout 
the education processes in schools, the principal has a central role in motivating all school personnel to achieve the educational goals (Anni, 2012).

The behavior of the principal who supports the guidance and counseling activities and wants to work with the counselor and hear input from the counselor will improve the performance of the counselor. The results of school leadership or consultative willingness to communicate with counselors are types of leadership that contribute to counselor performance and their good achievement (Dahir et al., 2011; Lawrence \& Stone, 2019; Shillingford \& Lambie, 2010).

The results of students' self-development are very well, this shows that counselors with counseling guidance services have been programmed and implemented, so students can make good use of the service. According to Mugiarso (2011) management of guidance and counseling covers several aspects, namely program planning and organizing, program implementation and direction, evaluation and supervision. Therefore, guidance and counseling service programs in schools are not possible to be organized and achieved if they are not managed in a good quality management system. Quality management itself will be largely determined by the ability of education management in schools in planning, organizing, directing and controlling available resources. Through guidance and counseling services students are assisted both individuals and groups, to become independent and develop optimally in personal, social, learning, and careers by the various types of services and support activities (Heilat \& Seifert, 2019; Hughes et al., 2017; Hussin et al., 2020; Rupani et al., 2014).

Guidance and counseling services try to help students find their personalities, in terms of knowing their strengths and weaknesses, and accepting themselves positively and dynamically for further self-development. The implication of this research is that the person in charge of guidance and counseling services can take advantage from the results of this study by studying the principal's leadership approach to improving student self-development.

The author acknowledges the limitation of this study. This study is only limited to two variables, principals' leadership and student self-development. In addition, the use of crosssectional research makes research data limited to one time data collection only. The use of self-report makes the possibility of filling the scale biased because it is very dependent on the cognitive abilities of participants in understanding the scale items. For further research, it is advisable to pay attention to the limitations of this study so that it can contribute to the development of science in this field in the future.

\section{CONCLUSIONS}

Based on the results of this study, it can be concluded that the principal's leadership in guidance and counseling services has been shown to have a positive relationship with student self-development. Thus student self-improvement can be enhanced through the leadership of the principal in the guidance and counseling service.

\section{ACKNOWLEDGEMENTS}

The author expresses his sincere appreciation to The Late Prof. Dr. Rochman Natawidjaja who had inspired the author to decide the topic of this paper and Prof. Dr. Taryat Trisnamansyah, M.A who had given abundant advice for this research.

\section{AUTHOR CONTRIBUTIONS STATEMENT}

Author conduct the research and manage to write the manuscript. 


\section{REFERENCES}

Anni, C. T. (2012). Need Assesment Model Penyusunan Program Bimbingan Dan Konseling Bidang Bimbingan Belajar Berbantuan Sistem Informasi Manajemen Di Sma Negeri Kota Semarang. Educational Management, 1(1). Retrieved from Google Scholar

Armstrong, S. A., MacDonald, J. H., \& Stillo, S. (2010). School Counselors and Principals: Different Perceptions of Relationship, Leadership, and Training. Journal of School Counseling, 8(15). Retrieved from Google Scholar

Balin, E., \& Hirschi, A. (2010). Who seeks career counselling? A prospective study of personality and career variables among Swiss adolescents. International Journal for Educational and Vocational Guidance, 10(3), 161-176. https://doi.org/10.1007/s10775010-9183-y

Bardhoshi, G., \& Duncan, K. (2009). Rural School Principals' Perception of the School Counselor's Role. Rural Educator, 30(3), 16-24. Retrieved from Google Scholar

Barida, M. (2016). Evaluasi Pelaksanaan Layanan Dasar Bidang Pribadi-Sosial Di Smp Negeri 1 Yogyakarta. Jurnal Fokus Konseling, 2(1), Article 1. https://doi.org/10.26638/jfk.128.2099

Coogan, P. A., \& Chen, P. C. P. (2007). Career development and counselling for women: Connecting theories to practice. Counselling Psychology Quarterly, 20(2), 191-204. https://doi.org/10.1080/09515070701391171

Dahir, C. A., Burnham, J. J., Stone, C. B., \& Cobb, N. (2011). Principals as Partners: Counselors as Collaborators: NASSP Bulletin. https://doi.org/10.1177/0192636511399899

Gysbers, N. C. (2001). School guidance and counseling in the 21st century: Remember the past into the future. Professional School Counseling, 5(2), 96. Retrieved from Google Scholar

Gysbers, N. C. (2004). Comprehensive guidance and counseling programs: The evolution of accountability. Professional School Counseling, 1-14. Retrieved from Google Scholar

Gysbers, N. C., \& Henderson, P. (2014). Developing and managing your school guidance and counseling program. John Wiley \& Sons. Retrieved from Google Scholar

Heilat, M. Q., \& Seifert, T. (2019). Mental motivation, intrinsic motivation and their relationship with emotional support sources among gifted and non-gifted Jordanian $\begin{array}{llll}\text { adolescents. } & \text { Cogent } & \text { Psychology, } & 6(1),\end{array}$ https://doi.org/10.1080/23311908.2019.1587131

Hughes, D., Law, B., \& Meijers, F. (2017). New school for the old school: Career guidance and counselling in education. British Journal of Guidance \& Counselling, 45(2), 133 137. https://doi.org/10.1080/03069885.2017.1294863

Hussin, U. R., Mahmud, Z., \& Karim, D. N. F. M. (2020). Psychoeducation group counselling for emotional intelligence among secondary school female students. Journal of Counseling, Education and Society, 1(2), 53-57-57. https://doi.org/10.2921/08jces48300

Keetanjaly, A., Abdul Kadir, S., Su Luan, W., \& Abdullah, A. (2019). The role of creativity in principals' leadership practices towards parental involvement: The mediating role of school practices and school climate. International Journal of Educational Management, 33(6), 1352-1365. https://doi.org/10.1108/IJEM-11-2018-0348

Komariah, A., \& Triatna, C. (2010). Visionary Leadership Menuju Sekolah Efektif, Bumi Aksara. Jakarata. Retrieved from Google Scholar

Kulsum, S. (2013). Peranan Bimbingan dan Konseling dalam Domain Pengembangan Diri Siswa 1. Jurnal Konseling Dan Pendidikan, 1(1), 67-72-72. https://doi.org/10.29210/11200 
Kurnianto, A. M. (2018). Pelaksanaan Layanan Dasar Bimbingan dan Konseling di Sekolah Dasar se-Kota Semarang. Indonesian Journal of Guidance and Counseling: Theory and Application, 7(4), 25-30. https://doi.org/10.15294/ijgc.v7i4.20040

Lawrence, A., \& Stone, C. (2019). Principals' Perceptions of Transformed School Counselors. NASSP Bulletin, 103(2), 139-157. https://doi.org/10.1177/0192636519853029

Leuwerke, W. C., Walker, J., \& Shi, Q. (2009). Informing Principals: The Impact of Different Types of Information on Principals' Perceptions of Professional School Counselors. Professional School Counseling, 12(4). https://doi.org/10.1177/2156759X0901200404

Lieberman, A. (2004). Confusion regarding school counselor functions: School leadership impacts role clarity. Education, 124(3). Retrieved from Google Scholar

Mugiarso, H. (2011). Bimbingan Konseling. Semarang: UNNES Press. Retrieved from Google Scholar

Norman C. Gysbers, P. H. (2012). Developing \& Managing Your School Guidance \& Counseling Programs (5th ed.). Wiley. Retrieved from Google Scholar

Pellitteri, J. S. (2010). Emotional intelligence in the context of adaptive personality: Implications for counselling psychology. Counselling Psychology Quarterly, 23(2), 129-141. https://doi.org/10.1080/09515071003775962

Pieterse, A. L., Lee, M., Ritmeester, A., \& Collins, N. M. (2013). Towards a model of selfawareness development for counselling and psychotherapy training. Counselling Psychology Quarterly, 26(2), 190-207. https://doi.org/10.1080/09515070.2013.793451

Ponec, D. L., \& Brock, B. L. (2000). Relationships among elementary school counselors and principals: A unique bond. Professional School Counseling, 3(3), 208. Retrieved from Google Scholar

Prayitno, E. A., \& Amti, E. (2004). Dasar-dasar bimbingan dan konseling. Jakarta: Rineka Cipta. Retrieved from Google Scholar

Rupani, P., Cooper, M., McArthur, K., Pybis, J., Cromarty, K., Hill, A., Levesley, R., Murdoch, J., \& Turner, N. (2014). The goals of young people in school-based counselling and their achievement of these goals. Counselling and Psychotherapy Research, 14(4), 306-314. https://doi.org/10.1080/14733145.2013.816758

Shillingford, M. A., \& Lambie, G. W. (2010). Contribution of Professional School Counselors' Values and Leadership Practices to Their Programmatic Service Delivery. Professional School Counseling, 13(4). https://doi.org/10.1177/2156759X1001300401

Shoffner, M. F., \& Williamson, R. D. (2000). Engaging Preservice School Counselors and Principals in Dialogue and Collaboration. Counselor Education and Supervision, 40(2), 128-140. https://doi.org/10.1002/j.1556-6978.2000.tb01244.x

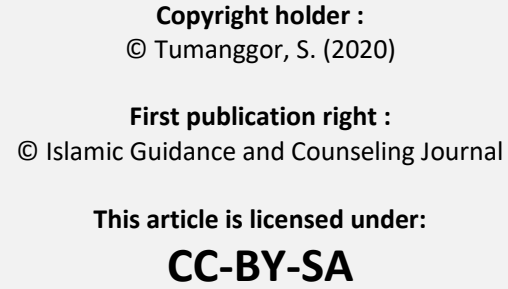

